\title{
CFHR1 Gene
}

National Cancer Institute

\section{Source}

National Cancer Institute. CFHR1 Gene. NCI Thesaurus. Code C124881.

This gene plays a role in complement regulation. 